\title{
Hizmet Kalite Algisinın Performansa Etkisi: Kocaeli Gölcük Tersanesinde Bir Uygulama
}

\author{
MAHMUT AKBOLAT* \\ makbolat@sakarya.edu.tr \\ ORCID ID: 0000-0003-3717-0508
}

\author{
SADIK SENAI ${ }^{* *}$ \\ senaisadik@gmail.com \\ ORCID ID:0000-0001-8791-8276
}

\author{
ÖZGÜN ÜNAL *** \\ ozgununal@sakarya.edu.tr \\ ORCID ID:0000-0002-1245-2456
}

Öz: Çalışmanın amacı Kocaeli Gölcük Tersanesi Bilgi İşlem Merkezinden (TEBİM) hizmet alan bireylerin hizmet kalitesi algılarını ve bu algının TEBİM'in performansina etkisini belirlemektir. Bu amaçla hizmet kalitesi ölçüm modellerinden SERVPERF modeli kullanılmıştır. Çalışmanın örneklemini Mart 2015'de TEBİM'den yüz yüze hizmet alan 230 kişinin 161'i oluşturmaktadır. Verilerin analizinde tanımlayıcı istatistiksel yöntemler, korelasyon ve regresyon analizlerinden yararlanılmıştır. Korelasyon analizi sonuçlarına göre ise SERVEPERF'in tüm boyutları ile müşterilerin TEBİM'den daha sonra hizmet alma düşünceleri, TEBİM tarafından sunulan hizmetlerin genel kalitesi ve TEBİM'in hizmetlerinden duydukları memnuniyet arasında da pozitif yönlü ve anlamlı ilişkiler bulunmaktadır. Ayrıca somutluk boyutu TEBİM tarafindan sunulan hizmetlerin genel kalitesine ilişkin algiyl; somutluk ve cevap verebilirlik boyutlar ise TEBİM'den daha sonra hizmet alma düşüncesini ve TEBİM'in hizmetlerinden duyulan memnuniyeti; pozitif yönlü etkilemektedir. Bu bulgular doğrultusunda TEBİM'in hizmet kalitesinin iyileştirilmesine yönelik yapılacak düzenlemelerin TEBİM'in performansını da olumlu yönde etkileyeceği söylenebilir.

Anahtar Kelimeler: Hizmet kalitesi, SERVPERF, TEBİM.

\section{Giriş}

Küreselleşme ve rekabetin büyük ivme kazandığı günümüz hizmet piyasalarında lider işletme olmak isteyen kuruluşların hizmet kalitesini geliştirmesi kaçınılmaz görülmektedir. Kaliteli hizmet sunumu için bir taraftan fiziksel koşulların iyileştirilmesi ve daha gelişmiş teknolojinin kullanılması, diğer taraftan da çalışanların hizmet kalitesi anlayışını benimseyerek çalışmaları bir zorunluluk olarak görülmektedir. Bunun için hizmet sunan örgütlerin kaliteye dayalı kültürü geliştirmeleri ve kaliteyi bir değer olarak gören personele sahip olmaları gerekmektedir. Bu sebeple işletmeler ne ürettiklerinden ziyade müşterilerin hizmeti nasıl algıladıkları üzerinde durmaları gerekmektedir. Literatüre bakıldığında bu amaçla geliştirilmiş farklı çalışmalar olduğu görülmektedir. Bu çalışmalar arasında Grönros tarafından geliştirilen

\footnotetext{
* Doç. Dr., Sakarya Üniversitesi, İşletme Fakültesi, Sağlık Yönetimi Bölümü.

${ }^{* *}$ Sakarya Üniversitesi, Sosyal Bilimler Enstitüsü, Sağlık Yönetimi Yüksek Lisans Öğrencisi.

*** Arş. Gör., Sakarya Üniversitesi, İşletme Fakültesi, Sağllk Yönetimi Bölümü.
} 
ve kendi adıyla bilinen model ${ }^{1}$, Parasuraman tarafından geliştirilen SERVQUAL ${ }^{2}$ ve SERVQUAL'in bir eleştirisi olarak, bu modelin geliştirilmesi ile Cronin ve Taylor tarafından geliştirilen SEVPERF modeli ${ }^{3}$ en çok kullanılan modellerdir.

Çalı̧̧ma planlanırken hizmet kalitesi modelleri üzerine çok sayıda çalışma olduğu saptanmış; ancak askeri hizmet sunma özelliği de bulunan Kocaeli Gölcük Tersanesi Bilgi İşlem Merkezine (TEBİM) benzer örgütlerde hizmet kalitesi konusunda Servperf ölçeğinin kullanıldığı bir çalışmaya rastlanılmamıştır. Özellikle yerli yazında yer alan çalışmalarda bankacılık, taşımacılık, sağlık, eğitim gibi sektörlerde hizmet kalitesi algısının ölçüldüğü, SERVPERF ölçeğinin ise az kullanıldığı görülmektedir. Bilgi işlem merkezlerinin hizmet kalitesini ölçen bir çalışmaya rastlanılmamış olmasına karşılık TEBİM gibi sadece tele hizmet vermeyen, aynı zamanda yüz yüze hizmette veren bir bilgi işlem merkezinde SERVPERF ölçeğinin uygulanması sadece tele hizmet veren çağrı merkezlerinin hizmet kalitesine ilişkin yol gösterici olacağı düşünülmektedir. Bu sebeplerden dolayı, bu çalışmada hizmet sektörünün farklı alanlarında kullanılan ve hizmet kalitesinin çeşitli boyutları ile ilgili algıyı ölçmeyi amaçlayan SERVPERF modelinin TEBİM’de test edilmesine karar verilmiştir.

\section{Literatür İncelemesi}

Hizmet, bir taraftan diğer bir tarafa sunulan bir hareket veya performanstır ${ }^{4}$. İhtiyaçlara uygunluk ${ }^{5}$ ve kullanımı karşılama ${ }^{6}$ örneklerinde olduğu gibi farklı şekillerde tanımlanan kalite ise herhangi bir ürünün, tüketicinin beklentilerini nasıl en iyi karşılayabileceğini keşfetmektir? . Müşteri bağlllığı ve memnuniyetini etkilediği için farklı sektörlerde hizmet sunan tüm şirketler hizmet kalitesinin ne kadar önemli olduğunun farkındadır. Ancak hizmet kalitesi bilgisini ortaya çıarmak için güvenilir bir araç kullanmak gerekir. Bunun için objektif ölçütlere ihtiyaç vardır. Ancak hizmetin üretim esnasında tüketilmesi ve üretilmeden önce satılması gibi özellikleri objektif ölçütlerin kullanılmasını imkânsız kılmaktadır. Objektif ölçütler olmadığı zaman, bir firmanın hizmet kalitesinin değerlendirilmesi için uygun bir yaklaşım müşterinin kalite algılarının ölçülmesidir. Ancak bu algıların ölçülmesi için kullanılabilecek kantitatif bir kıstas bulunmamaktadır?.

1 Christian Grönros, “A Service Quality Model and Its Marketing Implications”, European Journal of Marketing, 18/4 (1984).

2 Anantharanthan Parasuraman, A. Valarie Zeithaml ve Leonard L. Berry, "A Conceptual Model of Service Quality and Its Implications for Future Research", The Journal of Marketing, 49/4 (1985); Anantharanthan Parasuraman, Valarie A. Zeithaml ve Leonard L. Berry, "Servqual: A Multiple-Item Scale for Measuring Consumer Perceptions of Service Quality”, Journal of Retailing, 64/1 (1988).

3 Joseph Cronin ve A. Steven Taylor. "Measuring Service Quality: A Reexamination and Extension", The Journal of Marketing, 56/3 (1992).

4 Christopher Lovelock, Services Marketing People, Technology, Strategy, 4th ed., India: Pearson Education, 2000, s. 3.

5 Philip Crosby, "Paper Presented to the 'Bureau de Commerce”, Montreal, Canada (Unpublished), November (1984).

6 Joseph M. Juran, Juran on Planning for Quality, New York: Free Press, 1988, s.7.

7 William J. Stanton, Michael J. Etzel ve Bruce J. Walker, Fundamentals of Marketing, Ontario: McGraw-Hill College, 1994, s.4.

8 Hollis Landrum, Victor R. Prybutok ve Xiaoni Zhang, "A Comparison of Magal's Service Quality Instrument with SERVPERF”, Information \& Management, 44/1 (2007), s.106.

9 Parasuraman, Zeithaml ve Berry, "Servqual: A Multiple-Item Scale”. 
Parasuraman ve arkadaşları hizmet kalitesi üzerinde araştırmalar yaptıktan sonra hizmet kalitesi ölçümü konusunda üç kilit öneride bulunmuşlardır ${ }^{10}$ :

1. Tüketicinin hizmet kalitesini değerlendirmesi malların kalitesini değerlendirmesinden daha zordur;

2. Hizmet kalitesi algıları, tüketicilerin beklentilerini hizmetin gerçek performansı ile karşılaştırmalarından oluşmaktadır;

3. Kalite değerlendirmeleri sadece hizmet çıktısının sonucunu değil, aynı zamanda hizmet sunum sürecinin değerlendirmesini de kapsamaktadır.

Bu durumda algılanan kalite, bir varlığın bütünsel mükemmelliği veya önceliği hakkında tüketicinin yargılarıdır. Performans algısıyla, beklentilerin karşılaştırılmasıdır ve bir memnuniyetten daha çok bir tutum şeklidir ${ }^{11}$. Verilen bir hizmetin algılanan kalitesi, hizmeti alan ve algılayan tüketicinin beklentileri ile algılarının uyumlaştığı bir değerlendirme sürecinin sonucu olarak açıklanabilir. Tüketici beklenilen hizmete karşı algılanan hizmeti ifade eder. Bu sürecin sonunda algılanan hizmet kalitesi oluşacaktır. Bu nedenle hizmet kalitesi, beklenilen hizmet ve algılanan hizmet değişkenlerine bağımlıdır ${ }^{12}$.

Hizmet kalitesindeki bakış açılarının farklı olması, hizmet kalitesi ölçüm modellerinin de çeşitlenmesine sebep olmuştur ${ }^{13}$. Hizmet kalitesinin ölçümüne ilişkin ilk model Grönroos tarafından geliştirilen "Algılanan Hizmet Kalitesi Modeli"dir" ${ }^{14}$. Daha sonra Parasurman ve arkadaşları tarafından SERVQUAL ${ }^{15}$ ve Cronin ve Taylor tarafından hizmet kalitesi ölçümünde sadece müşteri algılarını esas alan SERVPERF modeli ${ }^{16}$ geliştirilmiştir. Hizmet kalitesinin ölçülmesinde Grönros, SERVQUAL ve SERPERF hizmet modeli sıklıkla kullanılmaktadır.

Grönros Modeli, hizmet kalitesini, teknik, fonksiyonel ve imaj olarak üç boyutta değerlendirilmesini önermektedir ${ }^{17}$. Teknik kalite, tüketicilerin hizmet firmasıyla etkileşimi sonucunda gerçekte ne aldığıdır. Fonksiyonel kalite, tüketicinin teknik sonucu nasıl aldığıdır. İmaj, hizmet firmaları için çok önemlidir ve imaj; gelenek, ideoloji, ağızdan ağıza iletişim ve halkla ilişkiler gibi faktörlerden etkilenen teknik ve fonksiyonel hizmet kalitesinin sonucunda oluşabilir ${ }^{18}$.

Parasuraman tarafından geliştirilen SERVQUAL ${ }^{19}$, genel hizmet kalitesinin ölçülmesi için bir çerçeve oluşturmakta ve bu çerçeve kamu ve özel sektör hizmetlerinin

10 Parasuraman, Zeithaml ve Berry, “A Conceptual Model of Service Quality”, s.42.

11 Parasuraman, Zeithaml ve Berry, "Servqual: A Multiple-Item Scale", s.17.

12 Grönros, “A Service Quality Model”, s.36-37.

13 Esen Gürbüz vd., "Algılanan Hizmet Kalitesinin Tatmin ve Davranışsal Niyet Üzerine Etkisi: Niğde İlindeki Süpermarketler Üzerine Ampirik Bir Çalışma”, Ege Akademik Bakış, 8/2 (2008), s.789.

14 Grönros, “A Service Quality Model”.

15 Parasuraman, Zeithaml ve Berry, "Servqual: A Multiple-Item Scale".

16 Cronin ve Taylor, "Measuring Service Quality".

17 Gi-Du Kang ve James Jeffrey, "Service Quality Dimensions: An Examination of Grönroos's Service Quality

Model”, Managing Service Quality: An International Journal, 14/4 (2004), s.267.

18 Grönros, "A Service Quality Model", s.38-40.

19 Parasuraman, Zeithaml ve Berry, "Servqual: A Multiple-Item Scale"; Parasuraman, Zeithaml ve Berry, "A Conceptual Model of Service Quality”. 
geniş bir alanında yaygın olarak kullanılmaktadır ${ }^{20}$. Parasuraman ve arkadaşları, hizmet kalitesini değerlendirmeye ilişkin araştırmalarında, hizmet kalitesinin etki alanının temel bir yapısı olarak kullanılan kriterleri somutluk, güvenilirlik, yanıt verme, iletişim, güvenilir olma, güvence, yeterlilik, incelik, tüketiciyi anlama/bilme ve erişim olmak üzere on boyutta sınıflandırmıştır ${ }^{21}$. Daha sonra SERVQUAL modeli yukarıdaki on boyutun tüm yönlerini kapsayacak -üçü orijinal ve ikisi birleşen- şekilde aşağıda açıklanan beş boyutta kısa tanımlara dönüştürülmüştür. Son iki boyut, -güven ve empati- yedi orijinal boyutu -iletişim, güvenilir olma, güvence, yetenek, incelik, tüketiciyi anlama/bilme ve erişimi- içerecek şekilde birleştirilmiştir ${ }^{22}$. Somutluk, fiziksel olanaklar, ekipman ve personelin görünüşü; güvenilirlik, güvenilir ve dakik olarak söz verilen hizmeti uygulama yeteneği; yanıt verme, tüketicilere yardım etme gönüllülüğü ve hizmeti tam zamanında sağlama; güven, çalışanların inceliği, bilgisi, güven ve dürüstlüğü telkin etme yetenekleri ve empati (duygu paylaşımı), tüketicilerin ihtiyaçlarını anlamak için gösterilen çaba ve kolay yaklaşılabilirlik şeklinde tanımlanmaktadır.

SERVQUAL'in orijinal versiyonu herhangi bir hizmet işletmesinde, tüketicilerin hizmet beklentilerini ölçmede 22 maddelik bir bölüm ve tüketici algılarını ölçmeye ilişkin diğer bir 22 parçalık bölüm olmak üzere, iki bölümden oluşmaktadır ${ }^{23}$. SERVQUAL ölçeğinin 22 maddeyi içeren ifadelerinin 1-4 arası somutluk, 5-9 arası güvenilirlilik, 10-13 arası cevap verme, 14-17 arası güvence ve 18-22 arası empati boyutunu oluşturmaktadır ${ }^{24}$.

SERVPERF modeli SERVQUAL modelini geliştirerek oluşturulmuştur. Cronin ve Taylor tarafından geliştirilen modele ${ }^{25}$ Babakus ve Boller yaptıkları çalışmayla kavramsal ve ampirik bakımdan önemli destekler sağlamışlardır ${ }^{26}$. Cronin ve Taylor başarıyı ölçmenin, uzun dönem hizmet kalitesi tutumlarını daha iyi yansıttığını iddia etmişlerdir ${ }^{27}$. SERVQUAL ölçeğinde belirtilen beklenti unsurundan vazgeçmişler ve yerine başarı unsurunu kullanmışlardır. SERVQUAL ölçeğindeki doğrulama yerine, sadece başarının önceliği fikrini desteklemişlerdir. SERVQUAL ölçeğinin bir çeşidi olan ve algılanan başarı unsurunu içeren başarı ölçeği, 22 ifadeden oluşmaktadır. Daha yüksek algılanan performans/başarı, daha yüksek hizmet kalitesi anlamına gelmekte ve SERVPERF modeli olarak bilinmektedir.

SERVQUAL ve kapsamlı hizmet kalitesi ölçüleri (SERVQUAL ve SERVPERF’in her

20 Marco Antonio Robledo, "Measuring and Managing Service Quality: Integrating Customer Expectations", Managing Service Quality: An International Journal, 11/1 (2001), s.23; Les Galloway, "Quality Perceptions of Internal and External Customers: A Case Study in Educational Administration", The TQM Magazine, 10/1 (1998), s.20-21.

21 Parasuraman, Zeithaml ve Berry, "Servqual: A Multiple-Item Scale".

22 Parasuraman, Zeithaml ve Berry, "A Conceptual Model of Service Quality”.

23 Cronin ve Taylor, "Measuring Service Quality".

24 Parasuraman, Anantharanthan, Leonard L. Berry ve Valarie A. Zeithaml, "Refinement and Reassessment of the SERVQUAL Scale", Journal of Retailing, 67/4 (1991).

25 Cronin ve Taylor, "Measuring Service Quality".

26 Emin Babakus ve Gregory W. Boller, "An Empirical Assessment of the SERVQUAL Scale”, Journal of Business Research, 24/3 (1992).

27 Cronin ve Taylor, "Measuring Service Quality". 
ikisi birlikte), tüketici beklentileri ve/veya tüketici algılamaları üzerine veri gerektirirken, performans/başarı sadece tüketici algılamaları üzerine veri gerektirmektedir. Veri gerektiren maddelerin sayısı SERVPERF ölçeği için sadece 22 iken, SERVQUAL ve kapsamlı SERVQUAL için 44 ve 66'dır. SERVPERF ölçeğinin 22 maddesi aynen SERVQUAL'de olduğu gibi, somutluk, güvenilirlik, yanıt verme, güvence ve empati boyutları altında sınıflandırılarak analiz edilmektedir ${ }^{28}$.

\section{Yöntem}

\section{Amaç}

Bu çalışmanın amacı, Kocaeli Gölcük’te faaliyette bulunan TEBİM'den hizmet alan kişi ve çalışanların TEBİM’in hizmet kalitesi faktörlerini nasıl değerlendirdikleri ve hizmet kalitesi faktörlerinin kullanıcıların daha sonra hizmet alma düşüncesini, genel hizmet kalitesini ve genel olarak TEBİM'den memnuniyetlerini etkileyip etkilemediğini ortaya koymaktır.

Hizmet sektöründe faaliyet sürdüren örgütlerin hizmet kalitesinin ölçümünde genellikle SERVQUAL, SERVPERF ve Grönroos modellerinden yararlanılmaktadır. Bu çalışmada SERVPERF modeli esas alınarak Kocaeli Gölcük Tersanesi TEBİM'den alan bireylerin hizmet kalitesine yönelik algıları ölçülmüştür. Bu sebeple çalışma yalnızca TEBİM ile sinırlıdır.

Araştırma alan incelemesine dayanmaktadır. Araştırmada veriler yüz yüze anket yöntemiyle elde edilmiştir. Çalışmada TEBİM'den hizmet alan kişilerin hizmet kalitesi algılarını ölçmek amacıyla Cronin ve Taylor tarafından geliştirilen SERVPERF ölçeğinden ${ }^{29}$ yararlanılmıştır. 25 ifadeden oluşan ölçeğin, ilk bölümünde hizmet kullanıcılarının kalite algılarını ölçmeye yönelik beş boyut ve 22 ifade (1-4. sorular somutluk, 5-9. sorular güvenilirlik, 10-13. Sorular cevap verebilirlik, 14-17. Sorular güvence ve 18-22. sorular empati) bulunmaktadır. Ölçeğin son üç ifadesi ise daha sonra hizmet alma düşüncesi, genel hizmet kalitesi ve genel olarak TEBİM'den memnuniyeti ölçmeyi amaçlamaktadır. Likert yapıda hazırlanan ölçekte; 1 kesinlikle katılmıyorum- 5 kesinlikle katılıyorum arasında sıralanmıştır. Ayrıca ankette katılımcıların sosyo-demografik özellikleri de yer almaktadır.

Çalışmanın evrenini TEBİM’den yüz yüze hizmet alan bireyler oluşturmaktadır. Çalışma 01 Mart 2015 ve 31 Mart 2015 tarihleri arasında yapılmış olup, bu dönemde TEBİM'den yüz yüze (230) ve telefon (450) ile hizmet alanların toplam sayısı $680 \mathrm{ki}$ şidir. Çalışmada sadece yüz yüze hizmet alan bireylerin katılımı amaçlanmış olup örneklem seçilmeden tüm evrene ulaşılması hedeflenmiştir. Ancak, çalışma sonucunda 161 (\%70) katılımcıya ulaşılabilmiştir. Araştırmadan elde edilen verilerin öncelikle geçerlilik ve güvenilirlik analizleri yapılmıştır. Verilerin analizinde tanımlayıcı

28 Cronin ve Taylor, "Measuring Service Quality”; Lawrence F. Cunningham, Clifford E. Young, ve Moonkyu Lee, "Cross-Cultural Perspectives of Service Quality and Risk in Air Transportation", Journal of Air Transportation, $7 / 1$ (2002); Sanjay K. Jain ve Gupta Garima, "Measuring Service Quality: SERVQUAL vs. SERVPERF Scales”, Vikalpa, 29/2 (2004).

29 Cronin ve Taylor, "Measuring Service Quality". 
istatistiksel yöntemler, korelasyon analizi ve regresyon analizinden yararlanılmıştır. Sonuçlar \%95'lik güven aralığında, $\mathrm{p}<0,05$ anlamlılık düzeyinde değerlendirilmiştir.

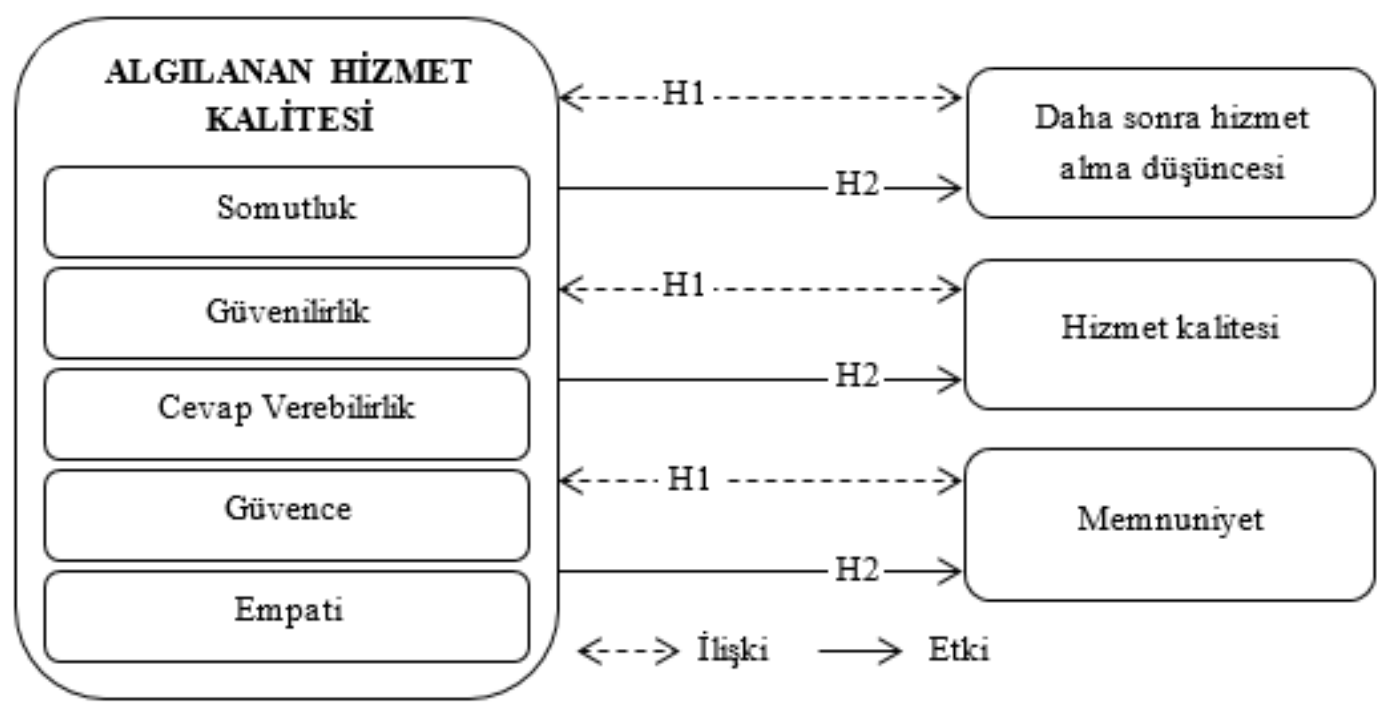

Şekil 1: Çalışmanın Modeli

Yukarıda çizilen modelden de yararlanılarak aşağıdaki hipotezler geliştirilmiştir.

H1. Hizmet kalite faktörleri ile daha sonra hizmet alma düşüncesi, hizmet kalitesi ve memnuniyet arasında istatistiksel açıdan anlamlı ilişki vardır.

H2. Hizmet kalite faktörleri, daha sonra hizmet alma düşüncesi, hizmet kalitesi ve memnuniyet üzerinde açılayıcı etkiye sahiptir.

\section{Geçerlilik ve Güvenilirlik Analizi}

Çalışmada kullanılan ölçeğin geçerlilik ve güvenirliğini test etmek amacı ile öncelikle ölçeğin kalite algısını ölçmeyi amaçlayan 22 ifadesi beş faktör halinde doğrulayıcı faktör analizine tabi tutuldu. Yapılan analiz sonucunda ölçeğe bozucu etkisi olan herhangi bir madde olmadığı tespit edildi. Analiz sonucu modelin uyum iyiliği (GFI) 0,945 ile kabul edilebilir düzeydedir. Düzeltilmiş Uyum İyiliği İndeksi (AGFI) 0,903, yaklaşık hataların ortalama karekökü (RMSEA) 0,054, Tucker-Lewis İndeksi (TLI) 0,957, normalize edilmiş uyum indeksi (NFI) 0,914, Artırımlı Uyum İyiliği İndeksi (IFI)- Delta 2 0,971 ve Karşılaştırmalı Uyum İndeksi (CFI) 0,970 bulundu. Ayrıca modelin Ki-kare değeri (CMIN) 45,212, serbestlik Derecesi (DF) 31, CMIN/ DF 1,458 ve $\mathrm{p}<0,05$ düzeyindedir.

Çalışmada geçerlilik analizinden sonra güvenilirlik analizi yapıldı. Güvenilirlik analizinde Cronbach's Alpha katsayısından yararlanıldı. Her bir boyutun ve ölçeğin tamamının Cronbach's Alpha katsayısı hesaplandı. Çalışmada kullanılan ölçeğin Cronbach's Alpha değeri 0,951 bulunmuştur. Ölçeği oluşturan boyutların Cronbach's Alpha değerleri 0,810-0,919 arasında değişmektedir. Cronbach's Alpha katsayısı l'e yaklaştıkça ölçeğin güvenilirliğinin artacağ ${ }^{30}$ dikkate alındığında, bu bulgular ölçeğin güvenilir olduğunu göstermektedir. 


\section{Bulgular}

Çalışmaya katılanların \%86,96'sı erkek ve \%83,85’i evlidir. Katılımcıların \%54,66'sı 36 ve üzeri yaşlarda olup; yaklaşık yarısı $(\% 49,69)$ lise eğitimi almıştır.

Tablo 1'de TEBİM'den hizmet alan bireylerin boyutlar itibari ile SERVPERF ölçeğine katılımlarının ortalama ve standart sapmaları görülmektedir. Katılımcıların genel katılımları orta düzeylerde olmakla birlikte; en yüksek katılım somutluk $(3,02 \bigotimes 1,370)$ boyutunda, en düşük katılım ise güvence $(2,05 \bigotimes 1,063)$ boyutunda görülmektedir. Somutluk daha çok sunulan hizmetin fiziksel yönünü ortaya koymakta, güvence ise çalışanların bilgili ve nazik olmasıyla müşterilere güven kazandırmasını ifade etmektedir. Bu bulgulara göre, TEBİM’in fiziksel koşulları daha olumlu bir bakış açısı oluşturmasına karşın, güven konusunda beklentilerin karşılanamadığg söylenebilir.

Tablo 1: SERVPERF Ölçeğinin Boyut ve Performans Değerlerinin Ortalaması

\begin{tabular}{|l|c|c|}
\hline & Ortalama & S.S. \\
\hline Algilanan hizmet kalitesi & 2,52 & 1,070 \\
\hline Somutluk & 3,02 & 1,370 \\
\hline Güvenirlik & 2,20 & 1,372 \\
\hline Cevap verebilirlik & 2,37 & 1,508 \\
\hline Güvence & 2,05 & 1,063 \\
\hline Empati & 2,93 & 1,192 \\
\hline Daha sonra hizmet alma düşüncesi & 2,65 & 1,455 \\
\hline Hizmet kalitesi & 3,19 & 1,488 \\
\hline Memnuniyet & 3,07 & 1,456 \\
\hline
\end{tabular}

Kalite algısını oluşturan faktörler ile performans faktörleri arasında bulunan ilişki Tablo2'de görülmektedir. Tablo incelendiğinde de anlaşılacağı gibi ölçeği oluşturan faktörler arasında 0,01 anlamlılık düzeyinde istatistiksel açıdan anlamlı ilişkiler bulunmaktadır. Ayrıca, Serveperf modelinin oluşturan boyutların tamamı ile müşterilerin TEBİM’den daha sonra hizmet alma düşünceleri, TEBİM tarafından sunulan hizmetlerin genel kalitesi ve TEBİM'in hizmetlerinden duydukları memnuniyet arasında da pozitif yönlü ve anlamlı ilişkiler bulunmaktadır. Bu bulgulara göre, $\mathrm{H} 1$ "Hizmet kalite faktörleri, daha sonra hizmet alma düşüncesi, hizmet kalitesi ve memnuniyet arasında istatistiksel açıdan anlamlı ilişki vardır." hipotezi kabul edilmiştir.

Tablo 2. Hizmet Kalitesi Faktörleri ile Hizmet Kalitesi, Memnuniyet ve Daha Sonra Hizmet Alma Niyeti Arasındaki İlişki

\begin{tabular}{|l|l|l|l|l|l|l|l|l|}
\hline & 1 & 2 & 3 & 4 & 5 & 6 & 7 & 8 \\
\hline Somutluk (1) & 1 & & & & & & & \\
\hline Güvenirlik(2) &, $541^{\star}$ & 1 & & & & & & \\
\hline Cevap Verebilirlik(3) &, $532^{\star}$ &, $853^{\star}$ & 1 & & & & & \\
\hline Güvence(4) &, $440^{\star}$ &, $732^{\star}$ &, $701^{\star}$ & 1 & & & & \\
\hline
\end{tabular}




\begin{tabular}{|l|l|l|l|l|l|l|l|l|}
\hline Empati(5) &, $551^{\star}$ &, $512^{\star}$ &, $517^{\star}$ &, $516^{\star}$ & 1 & & & \\
\hline Hizmet Toplam(6) &, $746^{\star}$ &, $898^{\star}$ &, $886^{*}$ &, $807^{\star}$ &, $757^{\star}$ & 1 & & \\
\hline $\begin{array}{l}\text { Daha sonra hizmet alma } \\
\text { düşüncesi (7) }\end{array}$ &, $413^{\star}$ &, $349^{\star}$ &, $384^{\star}$ &, $338^{\star}$ &, $351^{\star}$ &, $446^{\star}$ & 1 & \\
\hline Genel hizmet kalitesi (8) &, $457^{\star}$ &, $325^{\star}$ &, $343^{\star}$ &, $279^{\star}$ &, $340^{\star}$ &, $425^{\star}$ &, $556^{\star}$ & 1 \\
\hline Genel olarak memnuniyet (9) &, 511 &, $370^{\star}$ &, $416^{*}$ &, $312^{\star}$ &, $381^{\star}$ &, $486^{\star}$ &, $573^{\star}$ &, $865^{\star}$ \\
\hline
\end{tabular}

${ }^{\star *}$ Korelasyon 0.01 düzeyinde anlamlıdır.

Çalışmada hizmet kalite faktörlerinin müşterilerin daha sonra TEBİM’den hizmet alma niyeti, TEBİM tarafindan hizmetlerinin genel kalitesi ve TEBİM'den duyulan genel memnuniyet üzerine etkilerini analiz etmek amacıyla üç adet regresyon modeli geliştirilmiştir. Geliştirilen modellerde yordayan değişken olarak hizmet kalite faktörlerini oluşturan somutluk, güvenilirlik, cevap verebilirlik, güvence ve empati ile genel olarak SERVPERF ölçeğinin hizmet kalitesini oluşturan ifadelerin aritmetik ortalamalarından yararlanılmıştır. Hizmet alma düşüncesi, hizmet kalitesi ve TEBİM hizmetlerinden duyulan memnuniyet ise yordanan değişkenler olarak kullanılmıştır.

Stepwise regresyon analizi yöntemi kullanılarak gerçekleştirilen ilk modelin birinci aşamasında güvenlik, cevap verebilirlik, empati ve güvence; ikinci aşamada ise güvenirlik, empati ve güvence boyutlarının daha sonra hizmet alma düşüncesi, üzerinde istatistiksel açıdan anlamlı bir yordayıcı etkisinin olmadığı bulunmuştur ( $p>0,05)$. Buna karşılık, ilk aşamada somutluk $(\mathrm{F}=32,648$; $\mathrm{p}=0,000)$ ve ikinci aşamada somutluk ve cevap verebilirlik boyutlarının daha sonra hizmet alma düşüncesi ( $F=20,792$; $\mathrm{p}=0,000)$ üzerinde istatistiksel açıdan anlamlı bir etkisinin olduğu bulunmuştur. Modelde ilişki katsayısı birinci aşamada 0,413 ve ikinci aşamada 0,456 bulunmuştur. Somutluğun daha sonra hizmet alma düşüncesini açıklamaya etkisi \%17,0; somutluk ve cevap verebilirlik boyutlarının birlikte daha sonra hizmet alma düşüncesini açılayıcı etkisi ise \%20,8'dir. Çalışmanın bulgularına göre $\beta$ katsayıları pozitif yönlüdür ve buna göre somutluk ve cevap verebilirliğin daha sonra hizmet alma düşüncesine ilişkin etkileri olumlu yöndedir (Tablo 3).

Tablo 3. Hizmet Kalitesi Faktörlerinin Daha Sonra Hizmet Alma Niyeti Üzerine Etkisi

\begin{tabular}{|c|c|c|c|c|c|c|c|c|c|}
\hline & \multicolumn{2}{|c|}{ 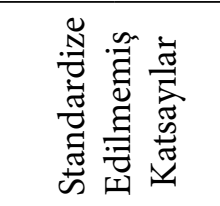 } & 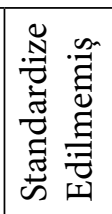 & \multirow[t]{2}{*}{$\mathrm{t}$} & \multirow[t]{2}{*}{$\mathrm{p}$} & \multirow[t]{2}{*}{$\mathrm{R}$} & \multirow[t]{2}{*}{$\mathrm{R}^{2}$} & \multirow[t]{2}{*}{$F$} & \multirow[t]{2}{*}{$\mathrm{p}$} \\
\hline & $\mathrm{B}$ & S.H. & $\beta$ & & & & & & \\
\hline (Sabit) & 1,324 & 0,254 & & 5,211 & 0,000 & \multirow{2}{*}{0,413} & \multirow{2}{*}{0,170} & \multirow{2}{*}{32,648} & \multirow{2}{*}{0,000} \\
\hline Somutluk & 0,438 & 0,077 & 0,413 & 5,714 & 0,000 & & & & \\
\hline (Sabit) & 1,189 & 0,254 & & 4,687 & 0,000 & \multirow{3}{*}{0,456} & \multirow{3}{*}{0,208} & \multirow{3}{*}{20,782} & \multirow{3}{*}{0,000} \\
\hline Somutluk & 0,309 & 0,089 & 0,290 & 3,474 & 0,001 & & & & \\
\hline $\begin{array}{l}\text { Cevap } \\
\text { Verebilirlik }\end{array}$ & 0,222 & 0,081 & 0,230 & 2,751 & 0,007 & & & & \\
\hline
\end{tabular}

Bağımsız Değişken: Daha Sonra Hizmet Alma Niyeti 
Çalışmada gerçekleştirilen ikinci regresyon modelinin sonuçları Tablo 4'de görülmektedir. Bu modelde regresyon modeli tek aşamada sonuçlanmıştır ve analiz sonucuna göre güvenlik, cevap verebilirlik, empati ve güvence faktörlerinin genel olarak hizmet kalitesi algısı üzerinde istatistiksel açıdan anlamlı bir yordayıcı etkisi bulunmamaktadır ( $\mathrm{p}>0,05)$. Buna karşılık, somutluk $(\mathrm{F}=41,949 ; \mathrm{p}=0,000)$ boyutunun hizmet kalitesi algısı üzerinde istatistiksel açıdan anlamlı bir etkisinin olduğu bulunmuştur. Somutluk boyutunun hizmet kalitesine ilişkin ilişki katsayısı 0,457 ve hizmet kalitesini açıklamaya etkisi \%20,9'dur. Çalışmanın bulgularına göre $\beta$ katsayısı $(0,457)$ pozitif yönlüdür ve buna göre somutluk genel olarak hizmet kalitesi algısını olumlu yönde etkilemektedir.

Tablo 4. Hizmet Kalitesi Faktörlerinin Hizmet Kalitesine Etkisi

\begin{tabular}{|c|c|c|c|c|c|c|c|c|c|}
\hline & \multicolumn{2}{|c|}{ 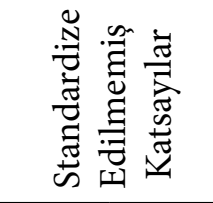 } & 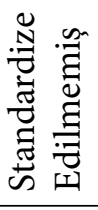 & \multirow[t]{2}{*}{$\mathrm{t}$} & \multirow[t]{2}{*}{$\mathrm{p}$} & \multirow[t]{2}{*}{$\mathrm{R}$} & \multirow[t]{2}{*}{$\mathrm{R}^{2}$} & \multirow[t]{2}{*}{$\mathrm{F}$} & \multirow[t]{2}{*}{ p } \\
\hline & B & S.H. & $\beta$ & & & & & & \\
\hline (Sabit) & 1,689 & 0,254 & & 6,658 & 0,000 & \multirow{2}{*}{0,457} & \multirow{2}{*}{0,209} & \multirow{2}{*}{41,949} & \multirow{2}{*}{0,000} \\
\hline Somutluk & 0,496 & 0,077 & 0,457 & 6,477 & 0,000 & & & & \\
\hline
\end{tabular}

Bağımsız Değişken: Hizmet Kalitesi

Somutluk, güvenlik, cevap verebilirlik, empati ve güvence faktörlerinin genel olarak hizmet kalitesi algısının memnuniyet üzerindeki etkisini ortaya koymak amacıyla gerçekleştirilen üçüncü model iki aşamada gerçekleşmiştir (Tablo 5).

Tablo 5. Hizmet Kalitesi Faktörlerinin Memnuniyet Üzerine Etkisi

\begin{tabular}{|c|c|c|c|c|c|c|c|c|c|}
\hline & \multicolumn{2}{|c|}{ 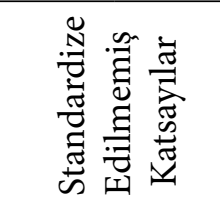 } & 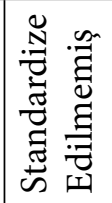 & \multirow[t]{2}{*}{$\mathrm{t}$} & \multirow[t]{2}{*}{$\mathrm{p}$} & \multirow[t]{2}{*}{$\mathrm{R}$} & \multirow[t]{2}{*}{$\mathrm{R}^{2}$} & \multirow[t]{2}{*}{$\mathrm{F}$} & \multirow[t]{2}{*}{$\mathrm{p}$} \\
\hline & B & S.H. & $\beta$ & & & & & & \\
\hline (Sabit) & 1,437 & 0,240 & & 5,990 & 0,000 & \multirow{2}{*}{0,511} & \multirow{2}{*}{0,261} & \multirow{2}{*}{56,210} & \multirow{2}{*}{0,000} \\
\hline Somutluk & 0,543 & 0,072 & 0,511 & 7,497 & 0,000 & & & & \\
\hline (Sabit) & 1,319 & 0,240 & & 5,488 & 0,000 & \multirow{3}{*}{0,539} & \multirow{3}{*}{0,290} & \multirow{3}{*}{32,275} & \multirow{3}{*}{0,000} \\
\hline Somutluk & 0,430 & 0,084 & 0,404 & 5,108 & 0,000 & & & & \\
\hline $\begin{array}{l}\text { Cevap } \\
\text { Verebilirlik }\end{array}$ & 0,194 & 0,076 & 0,201 & 2,534 & 0,012 & & & & \\
\hline
\end{tabular}

Bağımsız Değişken: Memnuniyet

Analizin birinci aşamasında güvenlik, cevap verebilirlik, empati ve güvence faktörlerinin; ikinci aşamada ise güvenirlik, empati ve güvence boyutlarının genel olarak memnuniyet üzerinde istatistiksel açıdan anlamlı bir yordayıcı etkisinin olmadığ 1 
bulunmuştur ( $p>0,05)$. Buna karşıllk, ilk aşamada somutluk $(\mathrm{F}=56,210 ; \mathrm{p}=0,000)$ ve ikinci aşamada somutluk ve cevap verebilirlik boyutlarının $(\mathrm{F}=32,275 ; \mathrm{p}=0,000)$ genel olarak memnuniyet üzerinde istatistiksel açıdan anlamlı bir etkisinin olduğu bulunmuştur. Modelde memnuniyete ilişkin ilişki katsayısı somutluk boyutu için 0,511 ve somutluk ve cevap verebilirlik boyutlarının her ikisi için 0,539'dur. Somutluğun genel olarak memnuniyeti açılamaya etkisi $\% 26,1$; somutluk ve cevap verebilirlik boyutlarının birlikte memnuniyeti açıklamaya açıklayıcı etkisi ise $\% 29,0$ bulunmuştur. Çalışmanın bulgularına göre $\beta$ katsayıları pozitif yönlüdür ve buna göre somutluk ve cevap verebilirliğin memnuniyeti açıklamaya etkilerinin olumlu yönde olduğu söylenebilir.

Geliştirilen regresyon modellerinden elde edilen bulgulara göre, somutluk ve cevap verebilirliğin daha sonra hizmet alma niyeti; somutluğun hizmet kalitesi ve somutluk ve cevap verebilirliğin memnuniyet üzerinde anlamlı yordayıcı etkisi bulunmaktadır. Buna karşılık diğer üç hizmet kalitesi faktörünü oluşturan güvenlik, empati ve güvence faktörlerinin her üç performans faktörü üzerinde anlamlı etkisi bulunmamaktadır. Bu bulgulardan hareketle $\mathrm{H} 2$. (Hizmet kalite faktörleri, daha sonra hizmet alma düşüncesi, hizmet kalitesi ve memnuniyet üzerinde açılayıcı etkiye sahiptir.) hipotezi güvenlik, empati ve güvence boyutları bakımından reddedilirken; daha sonra hizmet alma için somutluk ve cevap verebilirlik; hizmet kalitesi için somutluk ve memnuniyet için somutluk ve cevap verebilirlik boyutları için kabul edilmiştir.

\section{Sonuç}

$\mathrm{Bu}$ çalışmada bir bilgi işlem merkezi olan TEBİM’e ilişkin kullanıcıların hizmet kalitesi algıları ve performansa etkisi araştırılmıştır. Çalışmanın sonuçlarına göre en yüksek katılım somutluk $(3,02 \pm 1,370)$ boyutunda, en düşük katılım ise güvence $(2,05 \pm 1,063)$ boyutunda görülmektedir. Diğer boyutlardan güvenilirlik $(2,20 \pm$ $1,372)$; cevap verebilirlik $(2,37 \pm 1,508)$ ve empati $(2,93 \pm 1,192)$ için katılım orta seviyeye yakındır. Bu sonuçlara göre, TEBİM'in fiziksel koşulları ve çalışanların empati düzeyleri daha olumlu görünürken, güven, güvenilirlik ve yanıt verme konusunda beklentilerin yeterince karşılanamadığı görülmektedir. Daha önce yapılan somutluk, güvenilirlik, güvence, yanıt verme ve empati açıklamaları ışı̆̆ında düşünüldügünde; TEBİM'in yanıt verme, güven, güvenilirlik ve empati boyutlarındaki eksikliklerini gidermesi, somutluk boyutunda da geliştirici düzenlemeler yapması gerekli görülmektedir. Çalışmanın bir bilgi işlem merkezinde yapılmış olması ve bilgi işlem merkezinde hizmet kalitesi algısını ölçen bir çalışmaya rastlanılmamış olması nedeniyle çalışmanın sonuçları farklı sektörlerden çalışmalar ile karşılaştırılmıştır. Bu doğrultuda çalışmada ele alınan somutluk, güvenlik, güvenilirlik, cevap verebilirlik ve empati boyutlarının ortalamalarına ilişkin elde edilen sonuçlar farklı çalışmalar ile benzerlik ve farklılıklar göstermektedir. Örneğin hastane işletmeciliğinde hizmet kalitesi algısının ölçümüne yapılan bir tez çalışmasında boyutların ortalamaları düşük seviyede bulunurken ${ }^{31}$; bankacılık sektöründe yapılan bir çalışmada bu boyutların ortalamaları yüksek seviyede bulunmuştur ${ }^{32}$. Taşımacılık sektöründe yapılan

31 Sedef Sevimli, “Hizmet Sektöründe Kalite ve Hizmet Kalitesi Ölçümü Üzerine Bir Uygulama”, Yayınlanmamış Yüksek Lisans Tezi, İzmir Dokuz Eylül Üniversitesi, 2006, s.83.

32 Oğuz Işık, Mahmut Akbolat ve Mustafa Cahid Ünğan, "Kamu ve Özel Banka Müşterilerinin Hizmet Kalite 
bir araştırmanın bulguları ise çalışmanın bulguları ile benzerlik göstermektedir ve SERVPERF boyutlarının ortalamaları orta seviyeye yakındır ${ }^{33}$.

Hizmet kalite algısını oluşturan faktörler ile performans faktörlerinin tamamının arasında 0,01 anlamlılık düzeyinde istatistiksel açıdan anlamlı ilişkiler bulunmaktadır. Başka bir ifade ile hizmet faktörlerinin herhangi birinde meydana gelen olumlu bir değişim diğer faktörlerin de olumlu algılanmasına sebep olmaktadır. Ayrıca SERVPERF ölçeğinde performans kriteri olarak değerlendirilen daha sonra hizmet alma düşüncesi, genel hizmet kalitesi ve genel olarak TEBİM'den memnuniyetin hem kendi aralarında, hem de hizmet faktörleri aralarında olumlu ve yüksek düzeyde ilişki bulunmaktadır. Bu sonuçlar Işık, Akbolat ve Unğan’ın bankacılık sektöründeki çalışmalarının sonuçlarıyla ${ }^{34}$ ve havayolu taşımacılığı sektöründe yapılan Okumuş ve Asil'in çalışmalarının sonuçlarıyla ${ }^{35}$ benzerlik göstermektedir.

Çalışmada kullanılan regresyon modellerinden SERVPERF ölçeği boyutlarının daha sonra hizmet almayı düşünmeye etkisini belirlemeye yönelik kurulan modelin sonuçlarına göre ilk aşamada somutluk $(F=32,648 ; p=0,000)$ ve ikinci aşamada somutluk ve cevap verebilirlik boyutlarının daha sonra hizmet alma düşüncesi ( $F=20,792$; $\mathrm{p}=0,000)$ üzerinde istatistiksel açıdan anlamlı bir etkisinin olduğu bulunmuştur. Somutluk ve cevap verebilirlik boyutları bilgi işlem merkezi gibi bireylerin sorunlarına yardımcı olan veya onlara hizmetin kullanımına ilişkin yol gösteren bir alanda önemli boyutlar olarak dikkat çekmektedir.

Çalışmada kullanılan regresyon modellerinden SERVPERF ölçeği boyutlarının hizmet kalitesi algısına etkisini belirlemeye yönelik kurulan modelin sonuçlarına göre somutluk $(\mathrm{F}=41,949 ; \mathrm{p}=0,000)$ boyutunun hizmet kalitesi alg1sı üzerinde istatistiksel açıdan anlamlı bir etkisinin olduğu bulunmuştur. Hizmet kalitesi algısının \%20 ,9'unu somutluk boyutunun açıkladığı göz önüne alındığında, TEBİM kullanıcılarında daha olumlu bir hizmet kalitesi algısı oluşturmak için somutluk boyutuna ilişkin düzenlemelere önem verilmelidir.

Çalışmada kullanılan regresyon modellerinden SERVPERF ölçeği boyutlarının genel olarak TEBİM'den memnuniyete etkisini belirlemeye yönelik kurulan modelin sonuçlarına göre ilk aşamada somutluk $(\mathrm{F}=56,210 ; \mathrm{p}=0,000)$ ve ikinci aşamada somutluk ve cevap verebilirlik boyutlarının $(\mathrm{F}=32,275 ; \mathrm{p}=0,000)$ genel olarak memnuniyet üzerinde istatistiksel açıdan anlamlı bir etkisinin olduğu bulunmuştur.

Çalışmada kurulan üç farklı regresyon modelinin sonuçlarına göre somutluk ve cevap verebilirlik boyutlarının TEBİM’den memnuniyete ve TEBİM’i daha sonra kullanmaya etkisi olduğu, somutluğun ise hizmet kalitesi algısına etkisi olduğu görülmektedir. Bu sonuçlar doğrultusunda TEBİM’in fiziksel olanaklarında, ekipmanında ve personelin görünüşünde düzenlemeler ve iyileştirmeler yapılması ve yine TEBİM’in

Algılarının Değerlendirilmesi: Bir Alan Araştırması", Isşetme Bilimi Dergisi, 1/2 (2013), s.62.

33 Cenk Murat Koçoğlu ve Ramazan Aksoy, "Hizmet Kalitesinin Servperf Yöntemi ile Ölçülmesi: Otobüs İşletmeleri Üzerinde Bir Uygulama”, Akademik Bakış Dergisi, 29 (2012), s.13.

34 Işıı, Akbolat ve Ünğan, "Kamu ve Özel Banka Müşterilerinin”, s.62.

35 Abdullah Okumuş ve Hilal Asil, "Hizmet Kalitesi Algılamasının Havayolu Yolcularının Genel Memnuniyet Düzeylerine Olan Etkisinin İncelenmesi”, İstanbul Üniversitesi İsletme Fakültesi Dergisi, 36/2 (2007), s.23. 
hizmetten yararlanıcılara yardım etme gönüllülüğü ve hizmeti tam zamanında sağlama konularında geliştirmeler yapılması TEBİM kullanıcılarının memnuniyetini artıracak, TEBİM’e ilişkin hizmet kalitesi algısını yükseltecek ve TEBİM'i daha sonra tekrar kullanma konusunda tüketicileri teşvik edecektir. Ayrıca korelasyon analizinin sonuçları göz önüne alınarak olumlu hizmet kalitesi algısının TEBİM'in performansını da olumlu yönde etkileyecektir sonucuna ulaşılabilir. Bu nedenle çalışmada orta seviyenin altında bulunan güvenirlik, cevap verebilirlik, güvence ve empati boyutları ile orta seviyede bulunan somutluk boyutlarının geliştirilmesi için düzenlemeler yapılması önem arz etmektedir. Bu doğrultuda TEBİM'in fiziksel olanaklarını, ekipmanlarını, personelinin görünüşünü, güvenilir ve dakik olarak söz verilen hizmeti uygulama yeteneğini, tüketicilere yardım etme gönüllülüğünü, hizmeti tam zamanında sağlama yeteneğini geliştirmesi; çalışanların kibar, bilgili, güven telkin eden ve empati yeteneği gelişmiş bireyler olmasını sağlamak için çalışanlara ihtiyaç duydukları eğitimlerin sağlanması ve çalışanlar ile hizmetten faydalananalar arasında etkili iletişim kanallarının kurulması önerilebilir.

\section{Kaynakça}

Babakus, Emin ve Gregory W. Boller. "An Empirical Assessment of the SERVQUAL Scale". Journal of Business Research. 24/3 (1992): 253-268.

Cronin Joseph ve Steven A. Taylor. "Measuring Service Quality: A Reexamination and Extension". The Journal of Marketing. 56/3 (1992): 55-68.

Crosby, Philip. "Paper Presented to the 'Bureau de Commerce". Montreal, Canada (Unpublished), November (1984).

Cunningham, Lawrence F., Clifford E. Young ve Moonkyu Lee. "Cross-Cultural Perspectives of Service Quality and Risk in Air Transportation". Journal of Air Transportation. 7/1 (2002): 3-26.

Galloway, Les. "Quality Perceptions of Internal and External Customers: A Case Study in Educational Administration". The TQM Magazine. 10/1 (1998): 20-26.

Grönros, Christian. "A Service Quality Model and Its Marketing Implications". European Journal of Marketing. 18/4 (1984): 36-44.

Gürbüz, Esen, Arzum Büyükkeklik, M. Yüksel Avcılar ve Murat Toksarı. “Algılanan Hizmet Kalitesinin Tatmin ve Davranışsal Niyet Üzerine Etkisi: Niğgde İlindeki Süpermarketler Üzerine Ampirik Bir Çalışma”. Ege Akademik Bakış. 8/2 (2008): 785-812.

Işık, Oğuz, Mahmut Akbolat ve Mustafa Cahid Ünğan. "Kamu ve Özel Banka Müşterilerinin Hizmet Kalite Algılarının Değerlendirilmesi: Bir Alan Araştırması". İşletme Bilimi Dergisi. 1/2 (2013): 51-64.

Jain, Sanjay K. ve Garima Gupta. "Measuring Service Quality: SERVQUAL vs. SERVPERF Scales”. Vikalpa. 29/2 (2004): 25-38.

Juran, Joseph M. Juran on Planning for Quality. New York: Free Press, 1988.

Kang, Gi-Du ve Jeffrey James. "Service Quality Dimensions: An Examination of Grönroos's Service Quality Model”. Managing Service Quality: An International Journal. 14/4 (2004): 266-277. 
Koçoğlu, Cenk Murat ve Ramazan Aksoy. "Hizmet Kalitesinin Servperf Yöntemi ile Ölçülmesi: Otobüs İşletmeleri Üzerinde Bir Uygulama”. Akademik Bakış Dergisi. 29 (2012): 1-25.

Landrum, Hollis, Victor R. Prybutok ve Xiaoni Zhang. "A Comparison of Magal's Service Quality Instrument with SERVPERF”. Information \& Management. 44/1 (2007): 104-113.

Lovelock, Christopher. Services Marketing People, Technology, Strategy, 4th ed., India: Pearson Education, 2000.

Okumuş, Abdullah ve Hilal Asil. "Hizmet Kalitesi Algılamasının Havayolu Yolcularının Genel Memnuniyet Düzeylerine Olan Etkisinin İncelenmesi”. İstanbul Üniversitesi İsletme Fakültesi Dergisi. 36/2 (2007): 7-29.

Özdamar, Kazım. Paket Programlar ile İstatistiksel Veri Analizi. Eskişehir: Kaan Kitabevi, 1999.

Parasuraman, Anantharanthan, Valarie A. Zeithaml ve Leonard L. Berry. "A Conceptual Model of Service Quality and Its Implications for Future Research". The Journal of Marketing. 49/4 (1985): 41-50.

Parasuraman, Ananthanarayanan, Valarie A. Zeithamlve Leonard L. Berry. "Servqual: A Multiple-Item Scale for Measuring Consumer Perceptions of Service Quality”. Journal of Retailing. 64/1 (1988): 12-40.

Parasuraman, Anantharanthan, Leonard L. Berryve Valarie A. Zeithaml. "Refinement and Reassessment of the SERVQUAL Scale". Journal of Retailing. 67/4 (1991): 420-450.

Robledo, Marco Antonio. "Measuring and Managing Service Quality: Integrating Customer Expectations". Managing Service Quality: An International Journal. 11/1 (2001): 22-31.

Sevimli, Sedef. "Hizmet Sektöründe Kalite ve Hizmet Kalitesi Ölçümü Üzerine Bir Uygulama”. Yayınlanmamış Yüksek Lisans Tezi. İzmir Dokuz Eylül Üniversitesi. 2006.

Stanton, William J., Michael J. Etzel ve Bruce J. Walker. Fundamentals of Marketing. Ontario: McGraw-Hill College, 1994. 


\title{
The Impact of Service Quality Perception on Performance: An Application in Kocaeli Golcuk Shipyard
}

\author{
MAHMUT AKBOLAT \\ SADIK SENAI \\ ÖZGÜN ÜNAL
}

\begin{abstract}
The aim of this study to determine the service quality perceptions of the individuals whom receiving service from Kocaeli Gölcük Shipyard Data Processing Center (TEBIM) and the effect of this perception on the TEBIM's performance. SERVPERF model was used as service quality measurement. The sample of the study is 161 out of 230 persons who served face to face from TEBİM in March 2015. In the analysis of the data, descriptive statistical methods, correlation and regression analysis were used. According to the results of the correlation analysis, there are positive and significant relationships between the dimensions of the SERVEPERF and the customers' attitudes towards getting service again from TEBIM, the general service quality of the TEBIM, and satisfaction with TEBIM's services. In addition, the tangibility dimension has positive effect on the perception of the general service quality of the TEBIM; tangibility and responsiveness dimensions have positive effect on the customers' attitudes towards getting service again from TEBIM and satisfaction with TEBIM's services. According to these findings regulations to improve the quality of service of TEBIM could affect the performance of TEBIM positively.
\end{abstract}

Keywords: Service quality, SERVPERF, TEBIM. 